of main effects or interactions written for the Rothamsted computer were used for these analyses.

The statistical analysis of the data on birth-weight is described elsewhere (Barron and Vessey, in preparation).

We should like to express our thanks to the many people who have helped with this work, and especially to the Director, Mr. P. Payne, and Miss M. Martin and her staff of the South Metropolitan Cancer Registry, who did much of the data processing ; to Mrs. A. Moulton and Mrs. M. Thomas, who so painstakingly abstracted the case notes ; to Mr. Hammond and his staff of the medical records department at Lambeth Hospital ; and to Mrs. E. Thompson for secretarial assistance.

We are grateful to Miss L. Hurter and Mr. (now Professor) Philip Rhodes for permission to study patients under their care and to Professor Rhodes for his help and encouragement in the initiation of the study. Professor Sir Dugald Baird and his colleagues of the Obstetric Research Unit (M.R.C.) and Professor R. Illsley, of the Department of Sociology at Aberdeen, have given much advice and encouragement, and we are also grateful to Dr. Roma Chamberlain, of the Ministry of Health, for her help with background information.

The facilities for much of the analysis were made available through the kindness of Dr. F. Yates, F.R.S., head of the Department of Statistics, Rothamsted Experimental Station.

Financial assistance for the survey and analysis was provided by the Regional Research Committees of the South-west, and later, the North-east Metropolitan Regional Hospital Boards.

\section{REFERENCES} Baird, D. (1961). Path. et Microbiol. (Basel), 24, 557. Bertram. G. C. L. (1962). West Indian Immigration. Eugenics Society, London.
Central Statistics Office, Ireland (1960). Report on Vital Statistics for 1960. Dublin.

Comas, J. (1960). Manual of Physical Anthropology. Thomas, Springfield, Illinois.

Davies, P. D. B. (1963). Proc. roy. Soc. Med., 56, 565.

Davison, R. B. (1962). West Indian Migrants. Institute for Race Relations and Oxford University Press, London.

Doll, R., and Hanington, E. (1961). Path. et Microbiol. (Basel), 24, 531

Dyke, G. V., and Patterson, H. D. (1952). Biometrics, 8 , 1.

General Register Office (1960). Classification of Occupations. H.M.S.O.,

London.
Glass, R., and Pollins, H. (1960). Newcomers. Allen and Unwin, London.

Haines, M., and Taylor, C. W. (1962). Gynaecological Pathology. Churchill, London.

Jackson, J. A. (1963). The Irish in Britain. Routledge and Kegan Paul, London.

Lawson, J. B. (1961). Path. et Microbiol. (Basel), 24, 478.

London County Council (1959). Report of the County Medical Officer of Health, No. 4105.

of Health, Report of the County Medical Officer of Health, No. 4138.

McEwan, E. D. (1964). Lancet, 2, 744.

Miall, W. E., and Cochrane, A. L. (1961). Path. et Microbiol. (Basel), 24, 690 .

Miller, G. A. H., and Bamforth, J. (1961). Lancet, 2, 1452

Ministry of Health (1958). Report of Maternity Services Committee (Cranbrook). H.M.S.O., London.

Nelson, T. R. (1955). F. Obstet. Gynaec. Brit. Emp., 62, 48.

Patterson, Sheila (1964). Proc. roy. Soc. Med., 57, 325.

Registrar-General (1962). Statistical Review of England and Wales for 1960, Tables, Population, Part II. H.M.S.O., London. 1960, Tables, Population, Parc ti.

Ruck, S. K. (1960). The West Indian Comes to England. Routledge and Kegan Paul, London.

Springett V. H., Adams, J. C. S. D'Costa, T. B., and Hemming, M. (1958). Brit. Ұ. prev. soc. Med., 12, 135.

Steingold, L. (1962). In Recent Advances in Obstetrics and Gynaecology, edited by A. W. Bourne and L. H. Williams, 10th ed. Churchill, London.

United Nations (1960). Demographic Year Book, 1959. New York.

Waterhouse, J. A. H., and Brabban, D. H. (1964). Eugen. Rev., 56, 7.

Yates, F. (1955). Biometrika, 42, 382.

Yares, (1960) Sampling Methods for Censuses and Surveys, 3rd ed. Griffin, London.

\title{
Faecal Fat Excretion and Stool Colour After Vagotomy and Pyloroplasty
}

\author{
C. WASTELL, * F.R.C.s. ; HAROLD ELLIS, $\dagger$ D.M., M.CH., F.R.C.S.
}

Brit. med. F., 1966, 1, 1194-1197

Because of the popularity of vagotomy and pyloroplasty in the treatment of chronic duodenal ulcer, any nutritional defect resulting from this operation is of importance. The studies of Elliot-Smith, Painter, and Porter (1961), Cox, Bond, Podmore, and Rose (1964), Logan (1964), Orr (1964), and Butler and Eastham (1965) indicate that faecal fat excretion is raised after vagotomy and gastrojejunostomy. Information relating to this after vagotomy and pyloroplasty is lacking. with the exception of an investigation by Kiekens and Van Geertruyden (1963) of six patients in whom raised faecal fat excretion was also noted, and a study in Mysore by Tovey (1965), who found no significant difference in the mean faecal fat output between patients with total or selective vagotomy with pyloroplasty and controls.

In addition, it has been stated that after vagotomy and gastrojejunostomy the stools are lighter in colour (Grimson, Baylin, Taylor, Hesser, and Rundles, 1947 ; Burge, Rizk, Tompkin, Barth, Hutchison, Longland, McLennan, and Miln, 1961 ; Elliot-Smith et al., 1961 ; Cox and Bond, 1964 ; Goligher, Pulvertaft, and Watkinson, 1964), but a review of the subject fails to reveal any information about pigment excretion before and after operation.

The occurrence of diarrhoea after any operation involving vagotomy is extensively reported (Cox and Bond, 1964), but the incidence, severity, therapy, prophylaxis, and cause have for some time been a matter for discussion. At the present moment the most commonly advocated preventive measure is that of selective vagotomy, in which either or both of the main extragastric branches of the abdominal vagus are preserved (Burge, 1964).

This paper presents a study of the effect of vagotomy and pyloroplasty on faecal fat excretion, faecal urobilinogen excretion, and bowel frequency. In order to provide as accurate an investigation as possible only those patients were included for fat studies where detailed interrogation ensured that total faecal collections had been obtained-a source, we found, of considerable error. Patients with other intra-abdominal disease found at operation were also excluded.

The type of vagotomy was randomly distributed between total and anterior selective-that is, with preservation of the hepatic branch from the anterior vagus-so that the effect of the preservation of the vagal supply to the liver, biliary tree, head of the pancreas, and the first part of the duodenum could be determined.

* Lecturer in Surgery, Westminster Medical School, London. † Professor of Surgery, Westminster Medical School, London. 


\section{Material and Methods}

Patients included in this investigation were all admitted for operative treatment of a chronic duodenal ulcer. At operation the diagnosis was confirmed in each case and other significant gastro-intestinal disease excluded. Total abdominal vagotomy was performed in the standard manner via an upper midline incision. A short section of both vagi was excised, the ends being either ligated with thread or coagulated by diathermy. Anterior selective vagotomy was carried out as described by Burge (1964). The pyloroplasty was of Heineke-Mikulicz type, $8-10 \mathrm{~cm}$. long, sewn up with one layer of continuous $2 / 0$ chromic catgut, the completed suture line being covered with omentum.

Before the operation total faecal output was collected for five days. This collection of faeces was repeated in the ward one week after operation, and again six weeks or more postoperatively (range six weeks to 14 months, with a mean of six and a half months) as an outpatient.

The faecal collection was not delineated with carmine markers or enemata, because the third collection was after the patient had returned home. For the same reason the intake of fat was not controlled, and because a diet of 50 to $150 \mathrm{~g}$. of fat makes little difference to the faecal excretion of fat (Frazer, French, Sammons, Thomas, and Thompson, 1949). A normal western diet contains just this range of fat (Frazer, 1961) and a normal ward diet also falls within this range (Woodman and Yeoman, 1955).

Once voided, the faeces were put into a marked waxed carton, which was stored at $-8^{\circ} \mathrm{C}$. until the estimations were carried out at the conclusion of the collection.

Faecal fat was estimated by the technique of Kamer, Huinink, and Weyers (1949), the result being expressed in grams of fat (as fatty acid) excreted per 24 hours.

Faecal urobilinogen concentration was estimated by Maclagan's (1946) modification of Watson's (1937) method, the result being given as milligrams of urobilinogen per $100 \mathrm{~g}$. of stool.

The frequency of bowel action was assessed by carefully questioning the patient, which gives as good a mean figure as it is possible to obtain when dealing with so variable a quantity. The result is expressed as the mean number of bowel actions per day. After the operation at least six weeks (six weeks to 14 months, mean six and a half months) were allowed to elapse before the frequency was again recorded.

After the rigid exclusion of patients where other intraabdominal disease coexisted, or where we could not be certain that all the five-day faecal collections had been obtained, 20 patients were available for investigation of faecal fat excretion and urobilinogen concentration. Fourteen of these had undergone total vagotomy and six had had an "anterior selective" vagotomy. An additional three patients with anterior selective vagotomies, where stool collections were possibly incomplete, were included in the study of bowel frequency.

\section{Results}

\section{Faecal Fat Excretion}

These results are summarized in Tables I and II. After total vagotomy 11 out of the 14 patients showed a rise in the excretion of fat one week after operation, the mean value rising from 2.4 to $4.6 \mathrm{~g} . / 24$ hours. More than six weeks after operation there was again an increase in fat excretion compared with the pre-operative level in 13 out of 14 patients, and the mean had risen to 6.7 g. $/ 24$ hours. Similarly, when the patients after anterior selective vagotomy and pyloroplasty were considered one week after operation, four out of six showed an increase in the faecal fat excretion, the mean rising from 2.5 to $4.3 \mathrm{~g}$./
24 hours. Six or more weeks after operation all six patients excreted more fat than pre-operatively and the mean had risen to $6.4 \mathrm{~g} . / 24$ hours.

TABLE I.-Mean Faecal Fat Excretion (g./24 hours) Before (A), and One Week (B) and More than Six Weeks (C) After Total Vagotomy and Pyloroplasty

\begin{tabular}{|c|c|c|c|c|c|c|c|c|c|}
\hline Subject & Sex & $\mathbf{A}$ & B & C & Subject & Sex & A & B & C \\
\hline \multirow[t]{2}{*}{$\begin{array}{l}1 \\
2 \\
3 \\
4 \\
5 \\
6 \\
7 \\
8\end{array}$} & \multirow[t]{2}{*}{$\begin{array}{l}\mathbf{F} \\
\mathbf{M} \\
\mathbf{M} \\
\mathbf{M} \\
\mathbf{F} \\
\mathbf{M} \\
\mathbf{M} \\
\mathbf{M}\end{array}$} & \multirow[t]{2}{*}{$\begin{array}{l}2.30 \\
6.62 \\
1.94 \\
1.58 \\
4.77 \\
3.70 \\
1.77 \\
1.91\end{array}$} & \multirow[t]{2}{*}{$\begin{array}{l}2.68 \\
5.93 \\
0.17 \\
5.34 \\
4.58 \\
7.06 \\
9.18 \\
3.05\end{array}$} & \multirow[t]{2}{*}{$\begin{array}{r}8.31 \\
8.74 \\
11.20 \\
6.95 \\
5.67 \\
7.30 \\
6.46 \\
8 \cdot 12\end{array}$} & $\begin{array}{r}9 \\
10 \\
11 \\
12 \\
13 \\
14\end{array}$ & $\begin{array}{c}M \\
\mathbf{M} \\
\mathbf{F} \\
\mathbf{M} \\
\mathbf{M} \\
\mathbf{F}\end{array}$ & $\begin{array}{l}0.61 \\
0.99 \\
1.85 \\
3.80 \\
0.98 \\
1.05\end{array}$ & $\begin{array}{l}6 \cdot 89 \\
2 \cdot 83 \\
4 \cdot 62 \\
4 \cdot 72 \\
4 \cdot 63 \\
2 \cdot 44\end{array}$ & $\begin{array}{l}4.46 \\
3.85 \\
7.96 \\
3.06 \\
9.52 \\
2.14\end{array}$ \\
\hline & & & & & \multicolumn{2}{|c|}{$\begin{array}{l}\text { Mean } \\
\text { Standard } \\
\text { deviation }\end{array}$} & $\begin{array}{l}2 \cdot 42 \\
1 \cdot 65\end{array}$ & $\begin{array}{l}4 \cdot 58 \\
2 \cdot 29\end{array}$ & $\begin{array}{l}6.69 \\
2.50\end{array}$ \\
\hline
\end{tabular}

TABLE II.-Mean Faecal Fat Excretion (g./24 hours) Before ( $A$ ), and One Week (B) and More than Six Weeks (C) After Anterior Selective Vagotomy and Pyloroplasty

\begin{tabular}{c|c|c|c|c|c|c|c|c|c}
\hline Subject & Sex & A & B & C & Subject & Sex & A & B & C \\
\hline 15 & M & 3.10 & 2.81 & 4.59 & 19 & M & 1.02 & 4.05 & 7.28 \\
16 & F & 2.06 & 0.50 & 9.05 & 20 & M & 1.63 & 2.63 & 3.52 \\
17 & F & 0.74 & 3.39 & 4.16 & Mean & & 2.45 & 4.34 & 6.37 \\
18 & M & 6.12 & 12.63 & 9.62 & S.D. & & 1.81 & 3.87 & 2.41 \\
\hline
\end{tabular}

\section{Faecal Urobilinogen Concentration}

These results are summarized in Tables III and IV. The faecal urobilinogen was measured one week after operation, but the values were similar to those found six or more weeks after surgery and so have not been included.

TABLE III.-Mean Faecal Urobilinogen Concentration (mg./100 g. Stool) Before (A) and More than Six Weeks (B) After Total Vagotomy and Pyloroplasty

\begin{tabular}{|c|c|c|c|c|c|}
\hline Subject & A & B & Subject & A & B \\
\hline \multirow[t]{2}{*}{$\begin{array}{l}1 \\
2 \\
3 \\
4 \\
5 \\
6 \\
7 \\
8\end{array}$} & \multirow{2}{*}{$\begin{array}{r}83.5 \\
92.8 \\
47.9 \\
137.3 \\
42.1 \\
68.9 \\
102.5 \\
57.2\end{array}$} & \multirow{2}{*}{$\begin{array}{l}35 \cdot 8 \\
52 \cdot 1 \\
47 \cdot 3 \\
56 \cdot 7 \\
33 \cdot 8 \\
41 \cdot 6 \\
67 \cdot 5 \\
84 \cdot 2\end{array}$} & $\begin{array}{r}9 \\
10 \\
11 \\
12 \\
13 \\
14\end{array}$ & $\begin{array}{r}165 \cdot 8 \\
45 \cdot 2 \\
84.4 \\
54.5 \\
68 \cdot 8 \\
112.9\end{array}$ & $\begin{array}{l}32.9 \\
24.0 \\
33.9 \\
52.6 \\
58.4 \\
53.2\end{array}$ \\
\hline & & & $\begin{array}{l}\text { Mean } \\
\text { S.D. }\end{array}$ & $\begin{array}{l}83 \cdot 1 \\
35 \cdot 3\end{array}$ & $\begin{array}{l}48 \cdot 1 \\
15 \cdot 6\end{array}$ \\
\hline
\end{tabular}

TABLE IV.-Mean Faecal Urobilinogen Concentration (mg./100 g. Stool) Before $(A)$ and More than Six Weeks $(B)$ After Anterior Selective Vagotomy and Pyloroplasty

\begin{tabular}{c|r|r|r|r|r}
\hline Subject & A & B & Subject & A & B \\
\cline { 4 - 6 } 15 & 104.9 & $115 \cdot 0$ & 19 & 43.2 & 28.4 \\
16 & 38.1 & 7.0 & 20 & 147.9 & 51.8 \\
17 & $91 \cdot 0$ & $71 \cdot 1$ & Mean & 79.6 & 52.0 \\
18 & 52.5 & 38.5 & S.D. & 39.2 & 34.4 \\
\hline
\end{tabular}

In 13 out of 14 patients a reduction in the faecal urobilinogen concentration occurred six or more weeks after total vagotomy and pyloroplasty when compared with the pre-operation values; the mean fell from 83.1 to $48.1 \mathrm{mg}$. $/ 100 \mathrm{~g}$. stool. Similarly, after anterior selective vagotomy and pyloroplasty in five out of six patients a fall in the urobilinogen concentration was noted. The pre-operative mean value was $79.6 \mathrm{mg} . / 100 \mathrm{~g}$. stool, and six or more weeks later it was $52.0 \mathrm{mg} . / 100 \mathrm{~g}$.

After both total and anterior selective vagotomy there was a rise in the weight of faeces excreted per day (Tables V and VI). In the case of total vagotomy this rise was from a mean of 84.6 to $117.4 \mathrm{~g} . / 24$ hours, and in that of anterior selective vagotomy it was from 95.3 to $133.4 \mathrm{~g} . / 24$ hours.

From both the urobilinogen concentration and the bulk of the stool we can deduce the daily urobilinogen excretion in milligrams per 24 hours. After total vagotomy and pyloro- 
plasty it remained constant, the mean pre-operative figure being $61 \mathrm{mg} . / 24$ hours, and that at least six weeks after operation being $57 \mathrm{mg} . / 24$ hours. After anterior selective vagotomy and pyloroplasty, however, the mean urobilinogen excretion fell from $72 \mathrm{mg} . / 24$ hours pre-operatively to $54 \mathrm{mg} . / 24$ hours at more than six weeks after operation. These values are summarized in Tables VII and VIII.

TABLE V.-Mean Weight of Faeces Excreted (g./24 hours) Before $(A)$ and More than Six Weeks (B) After Total Vagotomy and Pyloroplasty

\begin{tabular}{|c|c|c|c|c|c|}
\hline Subject & A & B & Subject & A & B \\
\hline \multirow{2}{*}{$\begin{array}{l}1 \\
2 \\
3 \\
4 \\
5 \\
6 \\
7 \\
8\end{array}$} & \multirow{2}{*}{$\begin{array}{r}75 \cdot 12 \\
113 \cdot 20 \\
279 \cdot 17 \\
40 \cdot 13 \\
50 \cdot 81 \\
159 \cdot 33 \\
59 \cdot 70 \\
73 \cdot 46\end{array}$} & \multirow{2}{*}{$\begin{array}{r}182.92 \\
126.98 \\
104.96 \\
131.66 \\
90.32 \\
127.24 \\
108.32 \\
92.48\end{array}$} & $\begin{array}{r}9 \\
10 \\
11 \\
12 \\
13 \\
14\end{array}$ & $\begin{array}{l}22 \cdot 38 \\
54 \cdot 62 \\
50 \cdot 12 \\
65 \cdot 13 \\
75 \cdot 20 \\
66 \cdot 37\end{array}$ & $\begin{array}{r}68.07 \\
51.64 \\
104 \cdot 14 \\
85.10 \\
150.45 \\
129.96\end{array}$ \\
\hline & & & $\begin{array}{l}\text { Mean } \\
\text { S.D. }\end{array}$ & $\begin{array}{l}84 \cdot 62 \\
62 \cdot 66\end{array}$ & $\begin{array}{r}117.43 \\
39 \cdot 12\end{array}$ \\
\hline
\end{tabular}

TABLE VI.-Mean Weight of Faeces Excreted (g./24 hours) Before $(A)$ and More than Six Weeks (B) After Anterior Selective Vagotomy and Pyloroplasty

\begin{tabular}{|c|c|c|c|c|c|}
\hline Subject & A & B & Subject & A & B \\
\hline \multirow{2}{*}{$\begin{array}{l}15 \\
16 \\
17 \\
18\end{array}$} & \multirow{2}{*}{$\begin{array}{r}132.70 \\
126.03 \\
129.25 \\
92.46\end{array}$} & \multirow{2}{*}{$\begin{array}{r}81.20 \\
251.67 \\
62.62 \\
134.93\end{array}$} & $\begin{array}{l}19 \\
20\end{array}$ & $\begin{array}{l}52 \cdot 76 \\
38 \cdot 40\end{array}$ & $\begin{array}{l}103.80 \\
165.90\end{array}$ \\
\hline & & & $\begin{array}{l}\text { Mean } \\
\text { S.D. }\end{array}$ & $\begin{array}{l}95 \cdot 25 \\
37 \cdot 74\end{array}$ & $\begin{array}{r}133.35 \\
62.80\end{array}$ \\
\hline
\end{tabular}

TABLE VII.-Mean Faecal Urobilinogen Excretion (mg./24 hours) Before (A) and More than Six Weeks (B) After Total Vagotomy and Pyloroplasty

\begin{tabular}{c|r|c|c|c|c}
\hline Subject & A & B & Subject & A & B \\
\hline 1 & 62.7 & 65.5 & 9 & 37.1 & 22.4 \\
2 & 105.1 & 58.3 & 10 & 24.7 & 12.4 \\
3 & 133.7 & 92.3 & 11 & 42.3 & 35.3 \\
4 & 55.1 & $74 \cdot 7$ & 12 & 35.5 & 44.8 \\
5 & 21.4 & 30.5 & 13 & $51 \cdot 7$ & 87.9 \\
6 & 109.8 & 52.9 & 14 & 74.9 & $69 \cdot 2$ \\
7 & 61.2 & 73.1 & Mean & 61.2 & 56.9 \\
8 & 42.0 & 77.9 & S.D. & 32.5 & 23.9 \\
\hline
\end{tabular}

TABLE VIII.-Mean Faecal Urobilinogen Excretion (mg./24 hours) Before $(A)$ and More than Six Weeks After (B) Anterior Selective Vagotomy and Pyloroplasty

\begin{tabular}{|c|c|c|c|c|c|}
\hline Subject & $\mathbf{A}$ & B & Subject & A & B \\
\hline \multirow{2}{*}{$\begin{array}{l}15 \\
16 \\
17 \\
18\end{array}$} & \multirow{2}{*}{$\begin{array}{r}139 \cdot 2 \\
48 \cdot 0 \\
117 \cdot 5 \\
48 \cdot 5\end{array}$} & \multirow{2}{*}{$\begin{array}{l}93 \cdot 4 \\
17 \cdot 7 \\
44 \cdot 5 \\
52 \cdot 0\end{array}$} & $\begin{array}{l}19 \\
20\end{array}$ & $\begin{array}{l}22 \cdot 8 \\
56 \cdot 8\end{array}$ & $\begin{array}{l}29 \cdot 5 \\
85.9\end{array}$ \\
\hline & & & $\begin{array}{l}\text { Mean } \\
\text { S.D. }\end{array}$ & $\begin{array}{l}72 \cdot 1 \\
41 \cdot 6\end{array}$ & $\begin{array}{l}53.8 \\
27.6\end{array}$ \\
\hline
\end{tabular}

\section{Frequency of Bowel Action}

The pre- and post-operative frequency of bowel action of the group undergoing total vagotomy is shown in Table IX. Only 13 patients are considered, since one patient, with an average of one daily action after operation, had previously had ulcerative colitis, now entirely quiescent, which may have influenced his pre-operative bowel habit. Of these 13 patients the mean pre-operative bowel frequency was 0.9 bowel action per day, and post-operatively this rose to 1.6/day. Eight patients experienced an increase in the frequency of bowel action

TABLE IX.-Mean Frequency of Bowel Action/24 Hours Before and

\begin{tabular}{c|c|c|c|c|c}
\multicolumn{2}{c}{ a Least Six Weeks } & After Total Vagotomy and Pyloroplasty \\
\hline Subject & Before & After & Subject & Before & After \\
\hline 1 & 0.6 & 2.0 & 9 & 1.0 & 2.0 \\
2 & 1.0 & 1.0 & 10 & 1.0 & 2.0 \\
3 & 0.4 & 2.0 & 11 & 1.0 & 1.0 \\
4 & 1.0 & 1.5 & 12 & 0.3 & $2 \cdot 0$ \\
5 & 1.5 & 1.0 & 13 & 1.0 & 2.0 \\
6 & 2.0 & 2.0 & Mean & 0.9 & 1.6 \\
7 & 1.0 & 1.0 & 0.9 & 0.2 \\
8 & 0.2 & 1.4 & S.D. & 0.6 & \\
\hline
\end{tabular}

as a result of operation. In four patients the frequency remained the same.

Four patients suffered episodic attacks of increased frequency of bowel action associated with loose stools. In two an attack occurred approximately every three weeks, during which for from one to three days they would pass about three stools per day associated with some urgency. One patient suffered attacks of frequency of bowel action with considerable urgency, but without incontinence, whenever he travelled. The fourth patient had rare attacks which lasted from 3 to 24 hours, during which time she passed approximately five loose stools.

The frequency of bowel action after anterior selective vagotomy and pyloroplasty is summarized in Table $\mathrm{X}$. The mean frequency of bowel action rose from 0.9 per day pre-operatively to 1.9 per day post-operatively. The maximum frequency occurred in a patient who had 3.5 actions per day. No patient

TABLE X.-Mean Frequency of Bowel Action/24 Hours Before and at Least Six Weeks After Anterior Selective Vagotomy and Pyloroplasty

\begin{tabular}{|c|c|c|c|c|c|}
\hline Subject & Before & After & Subject & Before & After \\
\hline \multirow{2}{*}{$\begin{array}{l}15 \\
16 \\
17 \\
18 \\
19 \\
20\end{array}$} & \multirow{2}{*}{$\begin{array}{l}0.8 \\
1.0 \\
1.0 \\
1.0 \\
2.0 \\
1.0\end{array}$} & \multirow{2}{*}{$\begin{array}{l}1.0 \\
3.5 \\
1.5 \\
2.0 \\
2.0 \\
2.0\end{array}$} & $\begin{array}{l}21 \\
22 \\
23\end{array}$ & $\begin{array}{l}0.3 \\
0.4 \\
1.0\end{array}$ & $\begin{array}{l}1.0 \\
1.5 \\
2.5\end{array}$ \\
\hline & & & $\begin{array}{l}\text { Mean } \\
\text { S.D. }\end{array}$ & $\begin{array}{l}0.9 \\
0.5\end{array}$ & $\begin{array}{l}1.9 \\
0.7\end{array}$ \\
\hline
\end{tabular}

had diminished bowel frequency after operation, and no patient suffered episodic attacks of increased frequency. Of the nine patients in this group eight had noted an increase in the frequency of bowel action after operation.

\section{Discussion}

\section{Faecal Fat}

The rise in faecal fat excretion one week after total vagotomy and pyloroplasty is significant when compared with the preoperative level $(\mathrm{P}<0.01)$; however, significance cannot be demonstrated in the case of the increase noted one week after anterior selective vagotomy and pyloroplasty. In this latter case inability to show significance is probably due to the small number of patients. When fat excretion is examined at least six weeks after operation the increase over the pre-operative levels is significant after both total and anterior selective vagotomy and pyloroplasty $(\mathrm{P}<0.1$ respectively). It is not possible to demonstrate any significant difference between total and anterior selective vagotomy in this respect.

The accepted upper limit of normal for faecal fat excretion is $7 \mathrm{~g} . / 24$ hours : 10 of the 20 vagotomized patients in this study exceeded this level.

The findings of a significantly increased faecal fat excretion is in keeping with the observations of Kiekens and Van Geertruyden (1963), who found a mean faecal fat excretion of $11.3 \mathrm{~g} . / 24$ hours in six patients after vagotomy and pyloroplasty. Orr (1964) stated that the mean faecal fat excretion after vagotomy and pyloroplasty was just over $5 \mathrm{~g}$./day, but individual values were not given, and so the percentage of abnormal results included in this figure is not known.

Evidence is presented elsewhere (Wastell, 1966) that the rise in faecal fat excretion in the dog is due to the pyloroplasty rather than the vagotomy, the defect being caused by the widening of the outflow tract of the stomach. It is not surprising, therefore, that preservation of the extrinsic vagal supply to the hepatic and biliary tree makes no difference to fat excretion. Total vagotomy results in some dilatation of the gall-bladder and common bile-duct (Johnson and Boyden, 1952; Rudick and Hutchison, 1964), but these changes cannot be sufficient to interfere with the mixing of bile and fat essential for the latter's digestion and then absorption. 
The fact that there is a rise in the fat excretion to abnormal levels is of importance in two respects. The first is by virtue of loss of excess quantities of fat itself. It is unlikely that this will cause nutritional embarrassment by loss simply of calories, but steatorrhoea due to any cause may lead to loss of fat-roluble vitamins (Badenoch, 1960) and such ions as $\mathrm{Ca}^{++}$and $\mathrm{Mg}^{++}$ in the form of insoluble soaps. In particular, vitamin-D absorption may be deficient, with the result that calcium, already being excreted in excess, is not absorbed in adequate quantities. This may lead to a chronic negative calcium balance, resulting in the later development of osteomalacia. At present this chain of events is supposition only, but it is necessary to remember that, in patients who have undergone partial gastrectomy, osteomalacia has been reported 5 to 15 years after operation (Stammers and Williams, 1963).

The alteration in upper gastro-intestinal physiology is greater after partial gastrectomy than after vagotomy and pyloroplasty, and it would appear that the digestion and absorption of fat is impaired to greater degree following the former procedure (Orr, 1964). However, significant failure of absorption of fat has been demonstrated in half our patients, and if the serious late complication of osteomalacia is to be prevented early use of dietary supplements of calcium and vitamin D may be indicated. Secondly, increased fat excretion may be an index of malabsorption of other food materials. Baldwin, Albo, Jaffe, and Silen (1965) found that total stool nitrogen was increased, and Muyshondt and Schwartz (1964) noted impaired absorption of vitamin $B_{12}$ in dogs after total vagotomy and pyloroplasty. Thus, although vagotomy and pyloroplasty is perhaps the least physiologically disturbing of the operative procedures available for chronic duodenal ulceration, the processes of digestion and absorption are nevertheless significantly impaired.

\section{Stool Colour}

After total vagotomy and pyloroplasty the concentration of urobilinogen falls significantly $(\mathbf{P}<0.01)$. Since the urobilinogen excretion remains constant while the weight of faeces rises $(P<0.05)$, this fall in urobilinogen concentration is due to dilution.

Urobilinogen, a term used to include a class of compounds all derived by bacterial breakdown of bilirubin, is a colourless precursor of urobilin, which is itself responsible for most of the faecal colour (Watson, 1963). Hence, stool colour becomes reduced after total vagotomy and pyloroplasty, and this is due to the greater bulk of faeces passed after the operation.

After anterior selective vagotomy and pyloroplasty, although there is a decrease in the mean urobilinogen concentration due to a rise in faecal weight, and, in distinction to total vagotomy, a fall in urobilinogen excretion, significance cannot be demonstrated in any of these changes. This difference from total vagotomy may be due to the small number of patients available in this group.

\section{Bowel Frequency}

Our results agree with the observations of Cox and Bond (1964) in that bowel frequency changed in one of four distinct ways. In several patients, for up to two to four weeks after operation, there was a transient increase in bowel frequency, which later settled down. In one case there was a reduction in bowel frequency. In a few cases there were attacks of episodic increase in frequency, and in the majority of cases there was a moderate increase in bowel frequency after operation. In the patients reported here the mean increase in bowel frequency after both total and anterior selective vagotomy and pyloroplasty is significant $(P<0.1)$, but no significant difference can be demonstrated between these two operations in terms of this increase. It is realized, however, that this series is small and does not include an assessment of the urgency with which defaecation occurred, which is an important aspect of this problem. This subject is at present under investigation in a large series of patients.

\section{Summary}

Faecal fat excrction rises in nearly all patients after total and anterior selective vagotomy and pyloroplasty, and in half of them to abnormal levels.

Stool colour is diminished after total vagotomy and pyloroplasty owing to the dilution of faecal pigments. A similar trend is noted after anterior selective vagotomy and pyloroplasty.

Bowel frequency is usually increased by total and anterior selective vagotomy and pyloroplasty, but in a few cases there may be episodic increases of frequency or no change at all. Rarely there is a decrease in bowel frequency after operation.

In none of these quantities could any significant difference between anterior selective vagotomy and total vagotomy be demonstrated.

We are grateful to Miss Helen Scapetti for technical assistance and to Mrs. A. C. Kopec for statistical advice. This work was supported in part by a grant to one of us (C. W.) from the Research Committee of Westminster Hospital.

\section{REFERENCES}

Badenoch, J. (1960). Brit. med. F., 2, 879.

Baldwin, J. N., Albo, R., Jaffe, B., and Silen, W. (1965). Surg. Gynec. Obstet., 120, 777

Burge, H. (1964). Vagotomy. Arnold, London.

Rizk, A. R., Tompkin, A. M. B., Barth, C. E., Hutchison, J. S. F., Longland, C. J., McLennan, I., and Miln, D. C. (1961). Lancet, i, 897.

Butler, T. J., and Eastham, R. D. (1965). Gut, 6, 69.

Cox, A. G., and Bond, M. R. (1964). Brit. med. f., 1, 460.

Elliot-Smith, A., Painter, N. S., and Porter, R. (1961). Lancet, 2, 1036. Frazer, A. C. (1961). Fed. Proc., 20, Suppl. No. 7, p. 146.

M. D. (1949). Brit. F. Nutr., 3, 358. Goligher, J. C., Pulvertaft, C. N., and Watkinson, G. (1964). Brit. med. f., 1, 455 .

Grimson, K. S., Baylin, G. J., Taylor, H. M., Hesser, F. H., and Rundles, R. W. (1947). f. Amer. med. Ass., 134, 925.

Johnson, F. E., and Boyden, E. A. (1952). Surgery, 32, 591. biol. Chem., 177, 347. Kiekens, R., and Van Geertruyden, J. (1963). Acta gastro-ent. belg., 26,

Logan, H. (1964). Gut, 5, 188.

Maclagan, N. F. (1946). Brit. f. exp. Path., 27, 190.

Muyshondt, E., and Schwartz, S. I. (1964). Ann. Surg., 160, 788.

Orr, I. (1964). Ann. roy. Coll. Surg. Engl., 34, 314.

Rudick, J., and Hutchison, J. S. F. (1964). Lancet, 1, 579

Stammers, F. A. R., and Williams, J. A. (1963). Partial Gastrectomy ; Complications and Metabolic Consequences. Butterworth, London. Tovey, F. I. (1965). Indian f. Surg., 27, 317.

Wastell, C. (1966). In press.

Watson, C. J. (1937). In Handbook of Hematology, edited by $\mathrm{H}$. Downey, vol. 4, p. 2447. Hoeber, New York.

- (1963). f. clin. Path., 16, 1.

Woodman, D., and Yeoman, W. B. (1955). f. clin. Path., 8, 79. 